\title{
自然環境アセスメントの実態に関する研究
}

\section{A Study on Phenomena of Environment Impact Assessment for Nature Conservation}

\author{
東海林克彦* \\ Katsuhiko SHOJI
}

\begin{abstract}
摘要 : 自然環境アセスメントは，要綱や条例等に基づき，全国各地で実施されている。しかし，自然 環境アセスメントの実施状況の把握・分析や自然環境アセスメントが抱える問題点や課題の抽出・整 理は, 自然環境アセスメントの実施方法等に関して種々の改善すべき点の存在を指摘する意見がある にもかかわらず, 十分に行われているとは言い難い状況にある。本論はこのような状況を踏まえ，自 然環境アセスメントの今後のあり方を考える一助とするため, 主に技術的側面から自然環境アセスメ ントの実施状況を，可能な限り定量的なデー夕等に基づいて客観的・総合的に調查・分析し，問題点 や課題を明らかにしたものである。
\end{abstract}

\section{1. 背景及び目的}

現在，我が国の環境アセスメントは，環境影響評価実施要綱 (閣議決定), 各種法令・通達, 地方公共団体の条例・要綱等に基 づき全国各地で行われている。その件数はここ 20 余年で数千件 に及び，たくさんの運用実績が積み重ねられてきている。平成 5 年 11 月に成立した環境基本法の国会審議の過程では, 環境ア セスメント制度の法制化が大きな論議の的となり，総理大臣によ り，法制化む含め所要の見直しについて検討する旨の政府全体の 方針が示された。現在，この方針を受けて，環境广等においては， 環境アセスメントの制度や技術に関する検討が行われている。 また, 昭和 40 年代に大きな社会問題となった産業公害の問題か 危機的な状況を脱した中で，現在，自然環境の保全においては， 身近な自然の保全を含む多様な自然環境の体系的な保全や自然と の豊かなふれあいが求められており, 自然環境項目に係る環境ア セスメント（本論では「自然環境アセスメント」と称する）は, これらを実現するための有効な手段として期待されている。 ${ }^{31}$

このように自然環境アセスメントを取り巻く状況が変化しつつ ある中で, 今後, 自然環境アセスメントのあり方に関する検討が 数多くなされていくことになると考えられる。しかし，自然環境 アセスメントについては, 例えば保全目標が希少種中心であると か，行政に自然系の担当者が少ないなどといった制度面，運用面 及び技術面における種々の改善すべき点の存在を指摘する意見が あるにもかかわらず，その実施状況の把握・分析や自然環境アセ スメントが抱える問題点や課題の抽出・整理は十分になされてい るとはいえない状況にある。(1)576)このため, 本論では, 自然環境 アセスメントの今後のあり方を考える一助とするため, 自然環境 アセスメントを巡る昨今の状況の変化及びここ十数年の環境アセ スメントの運用実績の積み重称等を踏まえ，法制的側面からでは なく主に技術的側面から，自然環境アセスメントの実施状況を可 能な限り定量的なデー夕等に基づいて客観的・総合的に調查・分 析し，その問題点や課題を明らかにすることとしたものである。

\section{2. 調查方法}

本論において対象とした環境アセスメント制度は, 前述した調 査目的に鑑み，環境基本法第 20 条に規定されている環境了セス メント（環境影響評価）の定義, 対象事業の範囲, サンプル数と しての環境アセスメントの実施件数を考慮して，環境影響評価実
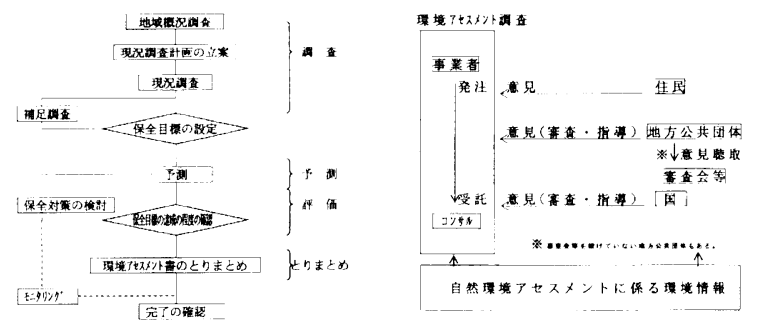

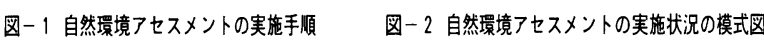
施要綱及び地方公共団体の条例または要綱とした。また, 雨環境 アセスメント制度は, 概ね威ー 1 に示した手順に従って, 図一 2 に模式的に示したような形で関係者が関与し（ただし, 国の関与 は条例・要綱アセスメントにおいてはない), 地形・地質, 植物, 動物, 景観, 野外レクリエーション地の 5 要素を自然環境項目の 基本的な環境要素として定めて実施している。(1)6)このため, これ らを踏まえて, 技術的側面から自然環境アセスメントの実態の全 体像を総合的に把握すべく, 表一 1 に示したように調査事項を整 理した。各調査事項に係る個別調査の方法の概要は, 表中に示し たとおりである。なお, 一部調査については, 資料の入手の可能 性及び作業量を考慮してサンプリング調査とした。また，必要に 応じて補足的にヒアリング調査を実施し，考察等の参考とした。

\section{3. 結果及び考察}

\section{(1) 環境アセスメント書調査}

(1) 構成

図ー3に見られるように環境アセスメント書の平均総頁数は, 条例・要綱アセスメントの方が多く, 閣議アセスメントの約 3 倍 となっている。内訳を見ると, 双方とも現況調査と予測で全体の 約 6 割を占めており, 自然系, 公害系別に「現況調查／予測」の 割合の比を見ると, 自然系は閣議決定アセスメント及び条例・要 綱アセスメントとも約 1.5 , 公害系は閣議アセスメントでは 0.4 , 条例・要綱アセスメントでは 0.6 となっており, 自然系は現況調 查重視型, 公害系は予測重視型の記述量となっている。また, 現 況調査及び予測の合計の「公害系／自然系」の割合の比は, 閣議 アセスメントでは 2.3 , 条例・要綱アセスメントでは 1.2 である。 農地や森林等に係る自然地域案件の割合はいずれも $90 \%$ 以上を 占めていることとあわせて考えると, 現況調査及び予測において 


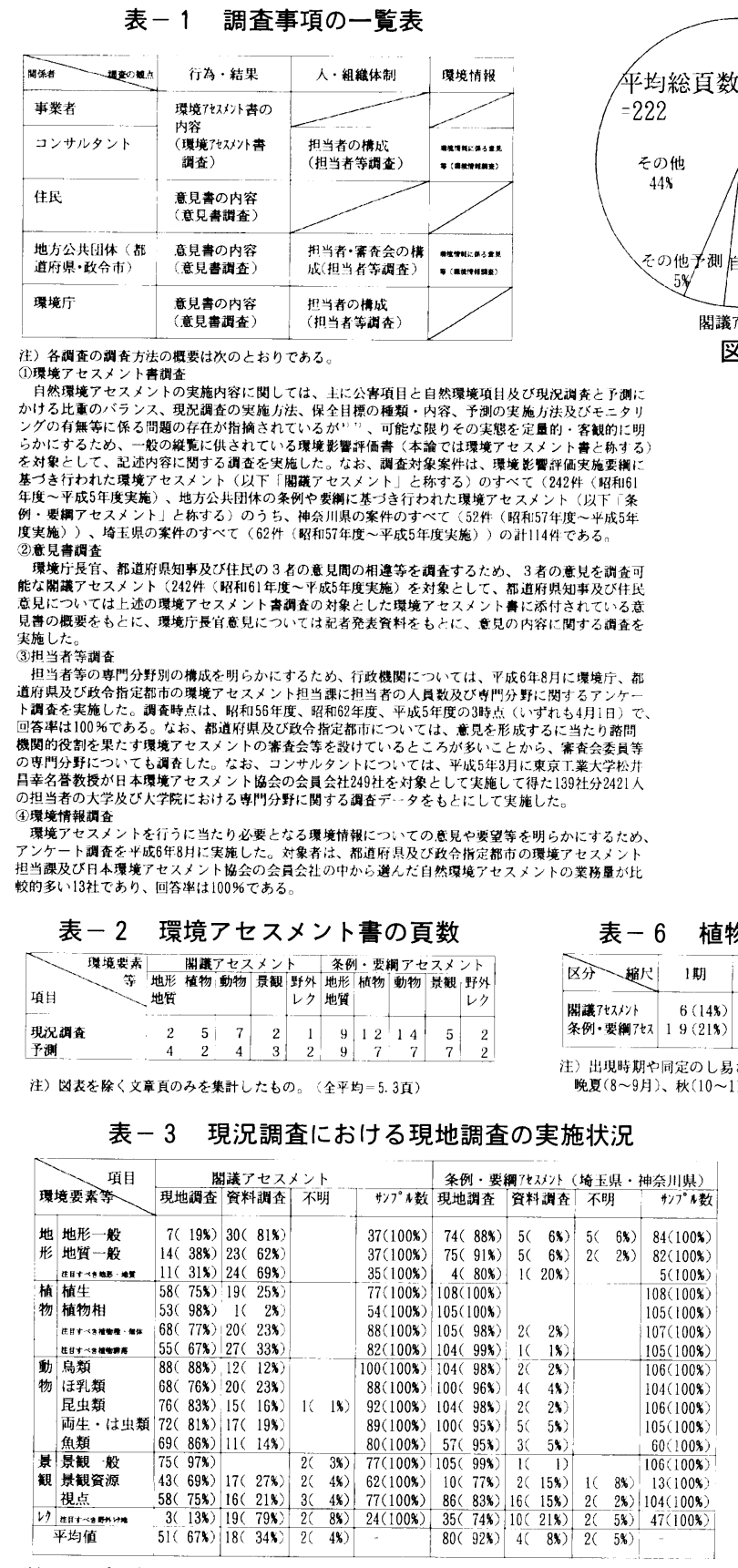

注）スコーピングによりア预が必要と判断されたものに限定して集㖕したものである。

\section{表 -4 現況調査の調査対象地域の範囲}

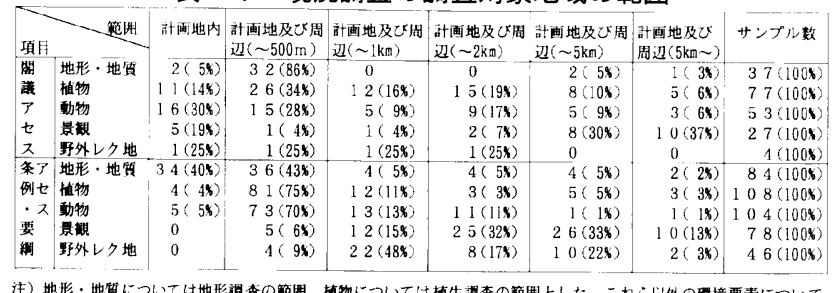

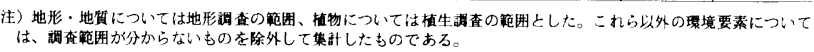

\section{表－5＼cjkstart現況調査における植生図の縮尺}

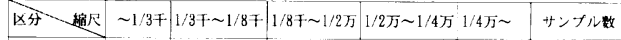

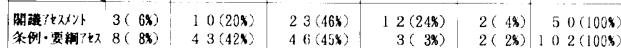

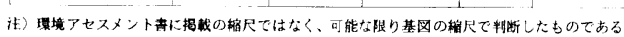

は相対的に閣議アセスメントは公害系重視の記述量であるといえ る。なお，表一 2 に見られるように環境要素別に見ると，現況調 査における動植物の記述量が各要素の平均頁数の 2 倍と多く, 野
外レクは現況調査, 予 測とも平均頁数の約半 分と記述量が少ない。 (2) 現況調查

表一 3 は, スコーピ ングにより予測が必要 と判断されたものにつ いて, 現況調査におけ る現地調查の割合を調 べたものである。環境

要素によってそれぞれに異なるが，平均では閣議アセスメントで は $67 \%$, 条例・要綱アセスメントでは $92 \%$ となっており, 閣議 アセスメントの方が資料調査ですます割合が高くなっている。環 境要素別に見ると, 条例・要綱アセスメントは現地調查率が低い あのでも $74 \%$ であが, 閣議アセスメントでは環境要素によっ て大きくばらついており, 地形・地質や野外レクリエーション地 において, 資料調查の割合が約 6 割 8 割と高率である。資料の 精度や調査時点にもよるであろうが，予測を行って影響の有無や 程度の判断をしなければならない場合に，現況調查を資料調査だ けですますことについては，一般的には問題が多いのではないか と考えられる。また, 表一 4 によれば, 調查対象範囲は, 環境要 素によって異なるが, 事業地のみにとどまっているものが数\%か ら数十\%ある。適正な調査対象範囲は, 環境要素每に, また, 対 象地域の環境特性により異なるものであって一律に示せるもので

はないが, 植生の連続性, 動物の行動範 囲や景観の視程を考慮すると事業地だけ にとどまることは決して適当ではないと 考えられる。なお，分析のし易さから植 物のみに限定しての詳細調査であるが, 现現調査における植生図の縮尺について調 べてみたところ， 2 万分の 1 より大縮尺の図面を使用しているも のが閣議アセスメントでは $28 \%$ ，条例要綱アセスメントでは $5 \%$ あった。計画地の平均規模が閣議アセスメントの面ものでは 207.0ha, 線ものでは $18.6 \mathrm{~km}$, 条例・要綱アセスメントの面もの では $60.7 \mathrm{ha}$, 線ものでは $3.3 \mathrm{~km}$ であるのに対して，2 万分の 1 の地形図ではよほど単純な植生でもない限りこのスケールオーダー で事業の実施が植生に与える影響を詳細に検討する，または理解 しやすいように表現するのは困難である。事業地の植生の特性等 を考慮した適正な縮尺の植生図が描けるような調査之植生図の作 成を行う必要があると考えられる。また，表一 6 は, 植物相の調 査時期を調べたものである。出現時期や同定のし易さを考えた場 合, フロラを網羅するような時期の 2 期の調査を行い得ていない と考えられる調查が約 4 割を占めている。フロラリストは, 保全 対象種の選定の基礎となる重要なものなので, 植物相調查は, 適 切な時期と回数を選んで行う必要があると考えられる。周)

(3) 保全目標

自然系の保全目標には，「希少種のイヌワシの厳正保護」など の特定の対象に係るもの之, それ以外の「緑地率 70\%の確保」 などの対象地域全体に係る自然環境保全上の一般的配虑事項（以 下，本論では「一般的配慮事項」之称する）に係るものの 2 種類 がある。 ${ }^{6)}$ 表一 7 によれば, 閣議アセスメント及び条例・要綱ア セスメントとも，特定の保全対象に係る保全目標の割合が約 8 割 から 9 割之一般的配慮事項に係るあのより多い。特に閣議了セス メントではその差が著しく，一般的配慮事項に係る保全目標の割 合は, 条例・要綱アセスメントが約 6 割であるのに対して 1 割に も満たない。両方の保全目標を併記しているもの屯, 条例・要綱 アセスメントでは約 4 割を占める件数であるのに対して, 閣議ア セスメントでは数件とごくわずかである。閣議アセスメントは, 
表 -7 保全目標の類型区分別の割合

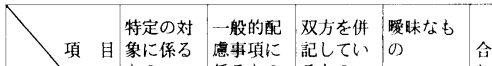

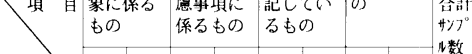

$$
\begin{aligned}
& \text { 区分 }
\end{aligned}
$$

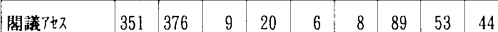

$$
\begin{aligned}
& \begin{array}{cc|c|c|c|c|c|c|c|}
\hline 80 \% & 85 \% & 2 \% & 5 * & 1 \% & 2 \% & 20 \% & 12 \% & 100 \%
\end{array} \\
& \begin{array}{ll|l|l|l|l|l|l|l|l}
\text { 条例・要絧7七又 } & 366 & 378 & 257 & 261 & 166 & 168 & 74 & 60 & 431
\end{array} \\
& \begin{array}{|l|l|l|l|l|l|l|l|l|}
\hline 85 \% & 88 \% & 60 \% & 61 \% & 39 \% & 39 \% & 17 \% & 14 \% & 100 \% \\
\hline
\end{array}
\end{aligned}
$$

条例・要綱アセスメントと異なり，技術指針により全国的価値， 都道府県的価値，市町村的価值等の $3 \sim 4$ 段階区分にあてはめて 保全目標を定めることとされている。このため,「緑地率 70\%の 確保等」の段階的な価值区分によるカテゴライズができない一般 的配慮事項に係る保全目標が少なく，特定の対象に係る保全目標 を偏重している傾向が顕著にあらわれているものと考えられる。 多様な自然環境の保全は，希少種等の特定の保全対象のみの保全 で達成できるものではなく，対象地域全体の自然環境の保全も必 要であることから, 特定の対象のみにとどまらない保全目標の設 定についての検討が必要であると考えられる。

(4) 予測

予測を行ったものについてその予測手法を調查したところ，閣 議アセスメント及び条例・要綱アセスメントの両方とも，景観の 予測についてはモンタージュ法によるものが多く，景観の予測数 全体の約 9 割を占めていた。景観以外の環境要素の予測について は，オーバーレイ法により貴重種等の特定の保全対象の消滅の有 無や程度を明らかにしたものが多く，それぞれの予測数全体の約 9 割を占めていた。なお，閣議アセスメント及び条例・要綱アセ スメントとも，景観のモンタージュを視点と景観資源との対応関 係を踏まえて行っているものは予測数全体の約 5 割であり, 残り の約 5 割は鳥瞰図等による単なる事業地の外観の变化を把握した 内容のものであった。また, 植物及び動物の予測については, 事 業地の周辺部にも保全対象は多数存在するから覀影響はないといっ たその保全に関して何の担保もない「周辺環境の現状維持」を前 提条件とした予測結果を出しているものも一部に見受けられた。 当該事業の環境負荷とバックグラウンドの累積的環境負荷を明ら かにし，環境負荷の限度量をどのように当該事業及びその他の事 業に配分するかについては，大気污染や水質污染の予測において も検討課題とされているところであるが，自然環境項目の予測に おいても同様に課題として位置づけられると考えられる。?

(5) モニタリング

自然環境のしくみは複雑であり，構成要素も多種多様であるこ とから，予測結果や保全対策の効果等には何某かの不確実性が残 る場合が多く，モニタリングによる結果の検証が必要である。9 モニタリングの実施を明記しているのは，閣議アセスメントでは 9 件, 条例・要綱アセスメントでは 1 件と少なく, モニタリング の実施の必要性について十分な検討が必要であると考えられる。

\section{(2) 意見書調査}

意見の種類別の案件数は表一 8 に示したとおりである。各意見 の合計数により意見の提出状況の相違を各環境要素別に見てみる と, 環境庁長官, 都道府県知事及び住民のいずれにおいても植物 及び動物に関する意見数がその他の環境要素に関する意見数に比 べて概ね 2 倍程度と多くなっている。保全上の問題の程度が各環 境要素間において同程度との仮定の下では, 植物及び動物の保全 に対する関心が相対的に高い傾向にあると考えることができる。

また，環境庁長官及び都道府県知事意見では，住民意見と異な り，環境アセスメント調榃のやり直しや追加調査を伴うことの多

表 -8 意見の種類別の案件数

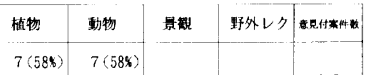

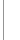

\begin{tabular}{|l|l|l|l|c}
$8(67 *)$ & $8(67 \%)$ & $7(588)$ & $7(586)$ & 12 \\
$(100 *)$
\end{tabular}

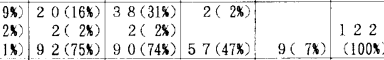

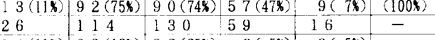

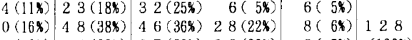
\begin{tabular}{|c|c|c|c|c|c|}
\hline $8(6 x)$ & $49(38 x)$ & $37(298)$ & $36(28 *)$ & $6(5 *)$ & $(100 \%)$ \\
\hline 42 & 120 & 115 & 70 & 20 & -
\end{tabular}

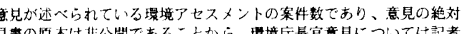

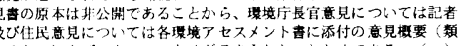

\begin{tabular}{|c|c|c|c|c|c|}
\hline 湎目 & 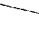 & 年度 & 昭利 156 午度 & 吸和 62 年度 & \%成 5 年度 \\
\hline If & 専任 & 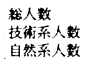 & $\begin{array}{ll}10 & 0 \\
10 & 0(100) \\
& 2(20)\end{array}$ & $\begin{array}{ll}1 & 0 \\
1 & 0 \\
2(1008) \\
2(20)\end{array}$ & $\begin{array}{l}8 \\
8(100 x) \\
2(25 s)\end{array}$ \\
\hline & 䁬任 & 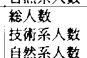 & $\begin{array}{l}3 \\
3(1008) \\
2(678)\end{array}$ & $\begin{array}{l}3 \\
3(1008) \\
2(678)\end{array}$ & $\begin{array}{l}3 \\
3(1000 \%) \\
1(33)\end{array}$ \\
\hline 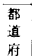 & 䙳任 & 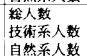 & $\begin{array}{l}2.7 \\
1.8(678) \\
0.2(78)\end{array}$ & $\begin{array}{l}2.1 \\
1.2(57 \%) \\
0.2(10 \%)\end{array}$ & $\begin{array}{l}2.2(50 *) \\
1.1(50 *) \\
0.3(48 *)\end{array}$ \\
\hline 望 & 阱任 & 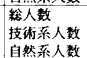 & $\begin{array}{l}2.5 \\
1.2(48 \%) \\
0.4(168)\end{array}$ & $\begin{array}{l}2.1 \\
1.1(52 \%) \\
0.3(146)\end{array}$ & $\begin{array}{l}1.7 \\
0.8(47 \%) \\
0.2(128)\end{array}$ \\
\hline 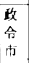 & 専任 & 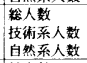 & $\begin{array}{l}3.0 \\
2.6(87) \\
0(0 \%) \\
\end{array}$ & $\begin{array}{l}1.8 \\
1.5(838) \\
0(08)\end{array}$ & $\begin{array}{l}2.4 \\
1.8(75 \%) \\
0(08)\end{array}$ \\
\hline & 研任 & 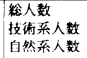 & $\begin{array}{l}2.0 \\
1.4(70) \\
0.3(15)\end{array}$ & $\begin{array}{l}1.5 \\
1.0(678) \\
0.4(278)\end{array}$ & $\begin{array}{l}0.4 \\
0.3(75 \times) \\
0(0 \times)\end{array}$ \\
\hline
\end{tabular}

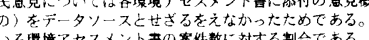

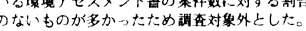
より効果的なものとするためには，合意形成の過程の透明性の確 保を図る何らかの措置が必要と考えられる。 ${ }^{10)}$ た, 中央公害対 策審議会答申によれば住民の機能は主に情報提供ということになっ ているが ${ }^{9)}$, 予測・評価の手法, 保全対策の有効性, 事業実施の

表 -9 行政機関における専門分野別の担当者数

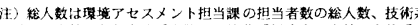

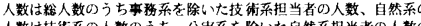

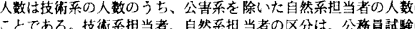

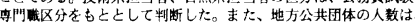

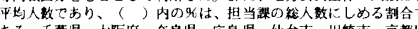

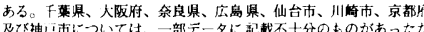

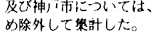
ける専任及び併任担当者の人員数を専門職区分別にとりま之めた あのである。農地や森林等に係る自然地域関係案件の取り扱いの 割合の高さ（環境庁 $91 \%$, 都道府県 75\%, 政令指定都市 33\%） に比べて, 表一 9 に示した自然系の技術担当者の人数の割合は, 環境庁では $25 \%$, 都道府県では 14\%, 政令指定都市では $0 \%$ と 総じて低くなっている。この傾向は，年度や併任の担当者を考慮 しても変わらず，各地方公共扵体に平均して見られる。自然環境 アセスメントは，環境基準等の数值的な基準の存在により統一的 かつ定量的な予测が行われることが多い公害項目に係る環境アセ スメントに対して，地域特性に応じてケースバイケースで保全目 標（保全対象及び保全水準等）の設定や予測手法の選択を行わな けれならず，専門的な能力なしには扱い難いものである。的適正 な自然環境アセスメントの推進を図るに当たっては, 行政機関に おける自然系の技術担当者の人員数について十分な手当が必要で あると考えられる。一方，都道府県及び政令指定都市の 59 中 47 が意見を形成するに当たり諮問機関的役割を果たす環境アセスメ ントの審査会等を設けているが，各地方公共村体の区分に基づき 集計した各委員の専門分野別の構成割合は図ー4に示したとおり である。自然系全体では $41 \%$ と特段の突出した割合ではないが， 自然系の中では動植物系が自然系の $54 \%$ 占めており，景観レ クリエーション系が $12 \%$ と少なくなっている。地方公共団体別

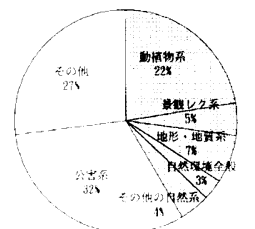

atsis

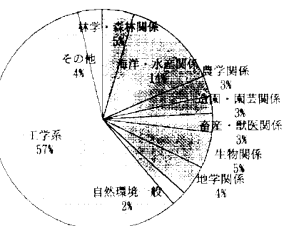

溥門分野別の委員及び担当者数 


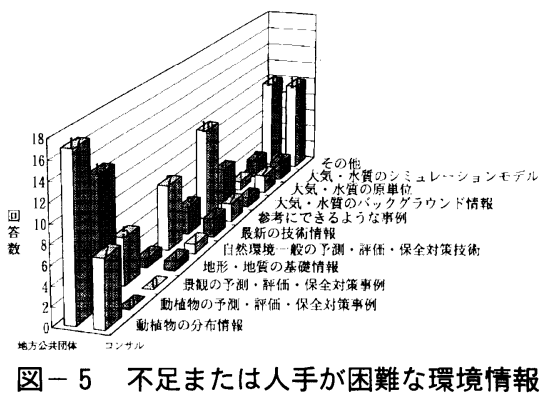

に個別に見ても動植物系の委員がいない審査会はないが，景観レ

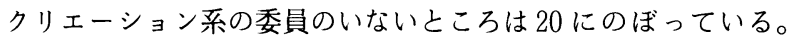
景観は, 環境の直観的・総合的指標として重要であるとともに, 関係住民に対するわかりやすいプレゼンテーションのッールとし ても有効なものである。 ${ }^{122}$ 審査会における景観の専門委員数につ いては十分な検討が必要であると考えられる。また，コンサル夕 ントの担当者は, 図一 4 のとおりであるが，分野別の業務量につ いて守秘義務等の制約があって調査できなかったため, 結果の考 察等は今後の課題とする。

\section{（4）環境情報調查}

審査や調查に当たって，不足または入手が困難と思われている 環境情報の種類は，図一 5 のとおりである。全体的に公害系より も自然系の環境情報の不足等を指摘する意見が多い。特に，動植 物に関する環境情報に関しては, 実際に環境アセスメントを行う 者にとって，事業地はともかくとしても事業地の周辺地域につい て詳細かつ広域的に環境情報を収集することは，原因者負担の原 則や他人の土地への立ち入り等の諸制約から困難な場合が多いこ と，また，そもそも対象が多くて時間变動むあるために調查が困 難であることから，その不足や入手の困難を指摘する意見が多い あのと考えられる。 ${ }^{5) 6}$ 環境情報の提供システムの必要性は， 1 県 を除く残りすべての者が認めており, 理由や効果に関しては, 図一 6 に示したように調査・審査精度の向上をあげるところが多く, 都道府県及び政令指定都市の 86\%，コンサルタントでは 100\%に のぼっている。ついで, 労力の軽減や費用の軽減を約半数があげ ており, 信頼性の確保や社会的費用の軽減の観点からその整備の 必要性は高いものであると考えられる。なお，現在，動植物の分 布情報等の収集調査に当たっての他人の土地への立ち入り調查権 については何の規定もないが, 調査対象範囲が事業地にとどまら ないこと，また，日本全国を対象とした詳細な分布情報をあらか

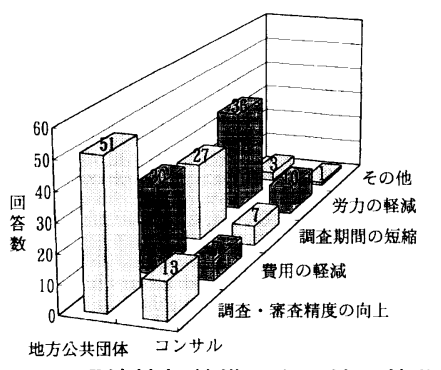

じめ統一的に整備しておくこ とは，作業量や費用等からいっ て現実的に困難であること等 を踏まえて, 制度上の検討が 必要であると考えられる。ま た，国及び地方公共団体が主 体となっての情報提供システ ムの整備を望む意見が約 8 割 ある一方，調査主体であるコ 図-6 環境情報整備の必要性や効果

は，事業者との契約上の守秘義務や情報の所有権の帰属問題によ り困難であるという指摘が約 9 割を占めており, 環境アセスメン トに必要な環境情報の公開性に関する検討も必要な状況となって いる。一方，モニタリングによる結果の検証情報の集積と一般的 公開は，予測技術や保全対策技術の知見の向上につながる重要な むのである。 リング報告書をすべて保管しているところは 4 割しかなく, 環境 アセスメント書をとってみても約 7 割となっている。さらに, 保 管されていたとしても，その一般公開については公開不可や貸し 出し不可などの制限を加えているところむあり, 環境アセスメン ト書やモニタリング報告書の公開と利用性の向上を図る必要があ ると考えられる。ただし，動植物の希少種等に関しては，その分 布情報が一般に自由に公開されたときの乱獲のおそれを危惧する 意見もあることから，公開や使用上の制限等の特別な配慮が必要

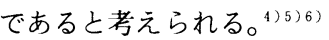

\section{4.おわりに}

現在，環境アセスメントについては，法制化等の制度面の課題 が大きくとりあげられている ${ }^{2)}$ が, 本論では, 自然環境アセスメ ントの技術的側面においても多くの課題が多方面にわたって存在 することを実証的に明らかにした。環境アセスメントは単なる通 過儀礼的な形式的手続きではなく，技術的に適切な内容のもので あることが必要である。観念的な議論が多い中で, 本論において 不十分ながらも自然環境アセスメントの実態や課題を明らかにし たことは，自然環境アセスメントが抱える多くの課題の解決に向 けての今後の検討の一助となるのではないかと考えている。最後 に, ご協力を頂いた環境庁企西調整局・自然保護局, 自然環境了 セスメント研究会に謝意を表する次第である。

\section{参考文献}

1 ）環境庁編 (1993)：日本の環境アセス メント：ぎょうせい

2 ）環境庁（1994）：環境庁記者発表資料 （環境影響評価制度総合研究会の設置 について）: 環境庁

3 ）環境庁編著（1994）: 環境基本法の解 説：ぎょうせい

4) 日本科学者会議編 (1985)：環境乃セ スメントの復権 : 北海道大学図書刊行 会

5 ）東海林克彦 (1994）：環境アセスメン
トと自然環境保全：「自治体・地域の 環境戦略 3 自然との共生を目指して (岡島成行編)」: ぎょうせい, 392-403

6 ) 自然環境アセスメント研究会 (1995): 自然環境アセスメント技術マニュアル： (財)自然環境研究センター

7 ）浜中裕徳（1981）：環境アセスメント 制度の問題点：大気污染学会誌 16(2), 77-87

8 ) 生態学実習懇談会編（1976）: 生態学 実習書 : 朝倉書店

9 ）日本環境協会編著：環境アセスメント
資料要覧 (上):第一法規，3-62

10）ジュリストNo695（1979）：特集・環 境アセスメント立法化の課題 : 有斐閣, $15-62$

11）環境庁（1995）：自然環境に係る環境 アセスメント手法の充実に関する調查 報告書 : 環境庁

12）熊谷洋一(1989)：景観アセスメント における予測評価手法に関する研究： 造園雑誌 53(1), 10-15

Summary : Environment impact assessment for nature conservation is widely and popularly implemented based on guideline of national government and by laws. However, some phenomena and problems of environment impact assessment for nature conservation has not been clarified entirely. This study aims to analyze phenomena of environment impact assessment for nature conservation technics and quantatives, and in order to contribute to improvement of the technical methods on environment impact assessment for nature conservation. 